\title{
KONTRIBUSI KEPEMIMPINAN, KECERDASAN SPIRITUAL, MOTIVASI KERJA DAN KEPUASAN KERJA TERHADAP KINERJA PEGAWAI DI LINGKUNGAN REKTORAT UNDIKSHA
}

\author{
Iwan Krisna, I Made Yudana, Sudirman \\ Program Studi Administrasi Pendidikan, Program Pascasarjana \\ Universitas Pendidikan Ganesha \\ Singaraja, Indonesia \\ e-mail: \{iwan.krisna, made.yudana, sudirman\}@pasca.undiksha.ac.id,
}

\begin{abstract}
Abstrak
Penelitian ini bertujuan untuk mengetahui kontribusi kepemimpinan, kecerdasan spiritual, motivasi kerja dan kepuasan kerja terhadap kinerja pegawai di lingkungan Rektorat Undiksha. Penelitian ini adalah penelitian "ex-post facto" dengan besar sampel 117 orang. Data dikumpulkan dengan kuesioner dan dokumen. Analisis data dilakukan dengan teknik regresi sederhana, regresi ganda, dan korelasi parsial. Hasil penelitian menunjukkan bahwa: 1) ada kontribusi yang signifikan antara kepemimpinan terhadap kinerja pegawai di lingkungan Rektorat Undiksha dengan koefisien korelasi sebesar 0,464 dan sumbangan efektifnya sebesar $7,61 \%$. 2) ada kontribusi yang signifikan antara kecerdasan spiritual terhadap kinerja pegawai di lingkungan Rektorat Undiksha. dengan koefisien korelasi sebesar 0,503 dan sumbangan efektifnya sebesar $9,04 \%$. 3) ada kontribusi yang signifikan antara motivasi kerja terhadap kinerja pegawai di lingkungan Rektorat Undiksha dengan koefisien korelasi sebesar 0,592 dan sumbangan efektifnya sebesar $14,65 \%$. 4) ada kontribusi yang signifikan antara kepuasan kerja terhadap kinerja pegawai di lingkungan Rektorat Undiksha dengan koefisien korelasi sebesar 0,574 dan sumbangan efektifnya sebesar $17,83 \%$. 5) secara bersama-sama, ada kontribusi yang signifikan antara kepemimpinan, kecerdasan spiritual, motivasi kerja, dan kepuasan kerja terhadap kinerja pegawai di lingkungan Rektorat Undiksha dengan koefisien korelasi ganda sebesar 0,701 dan kontribusinya sebesar $49,1 \%$ terhadap kinerja pegawai di lingkungan Rektorat Undiksha.
\end{abstract}

Kata kunci: kepemimpinan, kecerdasan spiritual, motivasi kerja, kepuasan kerja, kinerja pegawai

\begin{abstract}
This study aims to determine the contribution of leadership, spiritual intelligence, work motivation and job satisfaction on the performance of employees in the environment Undoris Rectorate. This study is an "expost facto" study with a sample size of 117 people. Data were collected with questionnaires and documents. Data analysis was performed by simple regression, multiple regression, and partial correlation. The results showed that: 1) there was a significant contribution between leadership on the performance of employees in Undiksha Rectorate environment with correlation coefficient of 0.464 and effective contribution of $7.61 \%$. 2) there is a significant contribution between spiritual intelligence on the performance of employees in the environment of Undiksha Rectorate. with a correlation coefficient of 0,503 and its effective contribution of $9.04 \%$. 3) there is a significant contribution between work motivation on employee performance in Undiksha Rectorate environment with correlation coefficient of 0,592 and effective contribution equal to $14,65 \%$. 4) there is a significant contribution between job satisfaction on the performance of employees in Undiksha Rectorate environment with correlation coefficient of 0,574 and effective contribution of $17,83 \%$. 5) jointly, there is a significant contribution between leadership, spiritual intelligence, work motivation, and job satisfaction on the performance of employees in the Undiksha Rectorate with a double correlation coefficient of 0.701 and its contribution of $49.1 \%$ to the performance of employees in the environment Rectorate Undiksha .
\end{abstract}

Keywords: leadership, spiritual intelligence, work motivation, job satisfaction, employee performance 


\section{PENDAHULUAN}

Perguruan tinggi merupakan suatu lembaga pendidikan yang bertujuan untuk mencetak sumber daya manusia yang mampu untuk bersaing dalam segala bidang. Untuk mencetak sumber daya manusia yang berkualitas, tentunya juga dibutuhkan sumber daya manusia yang berkualitas dari segi pegawainya. Untuk menjaga kualitas tersebut, perlu diadakan evaluasi terhadap kinerja pegawai.

Dengan melakukan evaluasi terhadap kinerja pegawai, maka akan dapat diketahui kinerja yang diberikan pegawai dalam melaksanakan tugas serta tanggung jawab yang diberikan. Menurut Sinambela (2012:5) kinerja pegawai didefinisikan sebagai kemampuan pegawai dalam melakukan sesuatu keahlian tertentu. Kinerja pegawai sangatlah perlu sebab dengan kinerja ini akan diketahui seberapa jauh kemampuan pegawai dalam melaksanakan tugas yang dibebankan kepadanya. Kinerja pegawai diartikan sebagai hasil evaluasi terhadap pekerjaan yang dilakukan individu dibandingkan dengan kriteria yang telah ditetapkan bersama (Robbins dan Coulter, 2012:143)

Permasalahan mengenai kinerja merupakan permasalahan yang akan selalu dihadapi oleh pihak manajemen baik di perusahaan maupun di lembaga pemerintahan, karena itu lembaga perlu mengetahui faktor-faktor yang mempengaruhi kinerja pegawainya.

Universitas Pendidikan Ganesha merupakan institusi pendidikan tinggi negeri yang mencetak sumber daya manusia dalam bidang kependidikan dan non kependidikan. Dalam bidang kependidikan, Universitas Pendidikan Ganesha merupakan pencetak sumber daya manusia pendidik yang terbesar di Bali. Sedangkan dalam non kependidikan Universitas Pendidikan Ganesha mencetak sumber daya manusia yang siap dipekerjakan di perusahaanperusahaan swasta maupun pemerintah. Untuk mendukung kelancaran dibidang administrasi dan pelayanan terhadap mahasiswa peran pegawai sangat penting sehingga kegiatan administrasi yang ada di Universitas Pendidikan Ganesha dapat berjalan dengan baik.

Berdasarkan observasi yang telah dilakukan terkait kinerja pegawai yang ada di Universitas Pendidikan Ganesha di Singaraja pada bagian humas misalnya masih sering terjadi informasi yang ada terkait kegiatan di Undiksha tidak diketahui secara detail, sehingga pencari informasi tidak mendapat apa yang ingin dicari, pada bagian kemahasiswaan, sering terjadi kurang adilnya penerima bea siswa di kalangan mahasiswa dan tidak tepat waktunya pencairan bea siswa. Sedangkan pada kegiatan akademik pada saat keluarnya nilai mahasiswa terjadi keterlambatan dari jadwal yang telah ditentukan. Selain itu untuk menyusun kartu rencana studi juga sering terjadi keterlambatan dari jadwal yang telah ditentukan sehingga membuat proses administrasi mahasiswa menjadi terlambat. Hal ini menyebabkan terjadinya antrian mahasiswa saat penyusunan kartu rencana studi serta pengesahan administrasi yang ada di bagian tata usaha fakultas. Hal-hal tersebut menunjukkan kurang siapnya pegawai dalam melaksanakan tugas serta tanggung jawab yang diberikan.

Berdasarkan permasalahan yang ada tersebut menunjukkan masih adanya hal-hal terkait kinerja pegawai Universitas Pendidikan Ganesha di Singaraja yang masih harus dikaji lebih lanjut. Dalam proses mancapai tujuan lembaga diperlukan pengukuran terhadap keberhasilan yang harus dicapai oleh setiap pegawai secara individu. Penilaian kinerja individu sangat bermanfaat bagi perkembangan lembaga secara keseluruhan, melalui penilaian kinerja pegawai tersebut maka dapat diketahui kondisi sebenarnya tentang bagaimana kinerja yang diberikan seorang pegawai pada lembaga tempatnya bekerja.

Salah satu faktor yang mempengaruhi kinerja pegawai yakni kepemimpinan. Kepemimpinan merupakan kemampuan untuk mempengaruhi antar pribadi atau kelompok, dalam situasi tertentu dan langsung melalui proses komunikasi untuk mencapai suatu tujuan yang telah ditetapkan. Pemimpin merupakan pribadi yang memiliki kecakapan dan kelebihan, sehingga mampu mempengaruhi orang lain untuk mencapai suatu tujuan.

Kecerdasan spiritual merupakan rasa moral, kemampuan menyesuaikan aturan yang kaku dibarengi dengan pemahaman dan cinta serta kemampuan setara untuk melihat kapan cinta dan pemahaman sampai pada batasannya, juga memungkinkan kita bergulat dengan 
ihwal baik dan jahat, membayangkan yang belum terjadi serta mengangkat kita dari kerendahan. Pegawai yang memiliki kecerdasan spiritual yang baik, biasanya perilakunya akan sabar, beretika, dan mampu melayani atau bekerja dengan sepenuh hatinya.

Selain kepemimpinan dan kecerdasan spiritual, motivasi juga mempunyai pengaruh terhadap kinerja pegawai dan menjadi salah satu faktor penting yang dialami oleh suatu lembaga, terutama mengenai apa saja yang bisa memotivasi pegawai dan bagaimana menyampaikannya pada para pegawai. Karena para pegawai juga ingin diperhatikan dan dihargai ketika bekerja, segala bentuk kepedulian lembaga terhadap pegawai akan membuat mereka merasa menjadi bagian penting dalam suatu organisasi atau lembaga. Lembaga hendaknya melakukan pemberian motivasi dengan baik dan benar, sesuai dengan kebutuhan dan keadaan di dalam kelembagaan. Walaupun terkesan sederhana, motivasi menjadi salah satu unsur yang mempunyai pengaruh penting terhadap kinerja pegawai.

Menjaga motivasi kerja pegawai itu sangatlah penting karena motivasi itu adalah motor penggerak bagi setiap individu yang mendasari mereka untuk bertindak dan melakukan sesuatu. Orang tidak akan melakukan sesuatu hal secara optimal apabila tidak mempunyai motivasi yang tinggi dari dalam dirinya sendiri untuk melalukan hal tersebut. Robin dan Judge (2008:222), mendefinisikan motivasi sebagai suatu proses yang menjelaskan intensitas, arah dan ketekunan seorang individu untuk mencapai tujuannya. Dari definisi tersebut dapat dicermati bahwa motivasi menjadi bagian yang sangat penting yang mendasari individu atau seseorang dalam melakukan sesuatu atau mencapai tujuan tertentu yang diinginkan. Masalah motivasi pada perusahaan haruslah dijadikan sebagai perhatian yang serius dalam manajemen sumber daya manusianya.

Selain dari motivasi kerja, faktor lain yang mempengaruhi kinerja pegawai yaitu kepuasan kerja. Kepuasan kerja para pegawai sangat penting dan besar perannya dalam kemajuan lembaga, karena bisa mempengaruhi berbagai kegiatan lembaga. Lembaga melalui manajemennya terus mengembangkan cara untuk meningkatkan kepuasan kerja pegawainya terutama pegawai-pegawai yang berprestasi dan bernilai tinggi dalam perusahaan.

Jika dilihat dari tingkat kepuasan kerja, masih adanya keluhan dari pegawai yang menunjukkan bahwa mereka belum merasa puas atas pekerjaannya. Tingkat kepuasan kerja ini tentunya akan berimbas pada kinerja yang ditunjukkannya. Kepuasan kerja pegawai menurut Hariandja (2002:291) dapat dilihat bahwa "pekerjaan tidak hanya sekedar melakukan pekerjaan, tetapi terkait juga dengan aspek lain seperti melakukan interaksi dengan teman sekerja, atasan, mengikuti aturan-aturan dan lingkungan kerja tertentu yang seringkali tidak memadai atau kurang disukai. "Kepuasan kerja pada dasarnya merupakan hal yang bersifat individual, setiap individual memiliki tingkat kepuasan kerja yang berbeda-beda sesuai dengan keinginan dan sistem nilai yang dianutnya (Handoko, 2000:192). Semakin banyak aspek dalam pekerjaannya yang sesuai dengan keinginan dan sistem nilai yang dianut individu, semakin tinggi tingkat kepuasan yang didapat.

Demikian pula sebaliknya, semakin banyak aspek dalam pekerjaannya yang tidak sesuai dengan keinginan dan sistem nilai yang dianut individu, semakin rendah tingkat kepuasan yang didapat. Kepuasan kerja adalah keadaan emosional yang menyenangkan dengan bagaimana para pekerja memandang pekerjaan mereka. Kepuasan kerja mencerminkan perasaan seseorang terhadap pekerjaannya yang dapat terlihat dari sikap karyawan terhadap pekerjaan dan segala sesuatu di lingkungan pekerjaannya. Semua jenis perusahaan sebenarnya membutuhkan suatu sistem kerja yang secara serius memperhatikan hal kepuasan kerja para karyawannya. Sebagaimana yang dikemukakan Handoko (1995:196) "Karyawan yang tidak memperoleh kepuasan kerja tidak akan pernah mencapai kematangan psikologis dan pada gilirannya akan menjadi frustasi."

Dengan kepemimpinan, kecerdasan spiritual, motivasi dan kepuasan kerja yang baik sudah seharusnya dapat menjadi suatu dorongan untuk menciptakan kinerja yang lebih maksimal dari seorang pegawai. Dengan kinerja yang maksimal dari setiap inidividu yang terlibat pada akhirnya diharapkan akan memberikan hasil yang terbaik terhadap kinerja 
organisasi secara keseluruhan. Sejalan dengan kondisi tersebut, maka perlu dilakukan kajian tentang Kontribusi Kepemimpinan, Kecerdasan Spiritual, Motivasi Kerja dan Kepuasan Kerja Terhadap Kinerja Pegawai di Lingkungan Rektorat Undiksha.

\section{METODE PENELITIAN}

Penelitian ini termasuk penelitian non-treatment atau ex-post facto karena tidak dilakukan perlakuan pada variabel dan hanya mengambil data secara langsung. Lebih lanjut, penelitian ini termasuk pendekatan kuantitatif dengan rancangan korelasional karena dalam penelitian ini mencoba mengetahui hubungan yang ada, antar variabel yang dikorelasikan. Hasil penelitian hanyalah mendeskripsikan dan menganalisis hubungan antara kepemimpinan, kecerdasan spiritual, motivasi kerja, dan kepuasan kerja terhadap kinerja pegawai di lingkungan Rektorat Undiksha.

Menurut Agung $(2014 ; 69)$ menyatakan populasi adalah keseluruhan objek dalam suatu penelitian. Sedangkan menurut Sugiyono (2009:61) populasi adalah wilayah generalisasi yang terdiri atas objek dan subjek yang mempunyai kualitas dan karakteristik tertentu yang ditetapkan oleh peneliti untuk dipelajari dan kemudian ditarik kesimpulannya.

Dari pendapat para ahli tersebut dapat ditarik kesimpulan bahwa populasi adalah subjek atau objek yang menjadi pusat penelitian yang memenuhi syarat-syarat tertentu yang berkaitan dengan masalah penelitian dalam suatu wilayah. Populasi dalam penelitian ini adalah seluruh pegawai di lingkungan Rektorat Undiksha sebanyak 167 orang.

Menurut Agung $(2016 ; 8)$ menyatakan bahwa sampel merupakan bagian dari populasi yang secara langsung dikenai penelitian. Sedangkan menurut Sugiyono (2009:62) sampel adalah bagian dari jumlah dan karakteristik yang dimiliki oleh populasi. Berdasarkan pendapat para ahli tersebut dapat ditarik kesimpulan bahwa sampel adalah bagian dari populasi dengan karakteristik yang dimiliki sama dengan populasi. Pengambilan sampel hendaknya representatif sehingga hasil kajian pada sampel dapat digeneralisasi pada populasi.

Pengambilan sampel dalam penelitian ini menggunakan pedoman tabel Morgan. Pada tabel tersebut dinyatakan bahwa apabila populasi berjumlah 167, maka sampel minimal yang harus diambil adalah sebanyak 117 orang. Sehingga sampel dalam penelitian ini digunakan sebanyak 117 orang. Penentual sampel dilakukan dengan teknik random sampling.

Variabel yang diteliti dalam penelitian ini meliputi variabel bebas (independent variable) dan variabel terikat (dependent variable). Variabel bebas $(X)$ yaitu variabel yang mempengaruhi variabel terikat. Sedangkan variabel terikat $(Y)$ adalah variabel yang dipengaruhi akibat adanya variabel bebas. Dalam penelitian ini variabel bebas meliputi: kepemimpinan $\left(X_{1}\right)$, kecerdasan spiritual $\left(\mathrm{X}_{2}\right)$, motivasi kerja $\left(\mathrm{X}_{3}\right)$ dan kepuasan kerja $\left(\mathrm{X}_{4}\right)$. Sebagai variabel terikat adalah kinerja pegawai di lingkungan Rektorat Undiksha $(Y)$.

Untuk pengumpulan data tentang kepemimpinan Pemimpin, kecerdasan spiritual, motivasi kerja dan kinerja pegawai digunakan kuesioner dengan pola skala likert. Sementara itu, Riduwan (2005:25) berpendapat bahwa "angket (questionnaire) adalah daftar pertanyaan yang diberikan kepada orang lain yang bersedia memberi respons (responden) sesuai dengan permintaan pengguan. Sedangkan untuk memperoleh jumlah pegawai yang ada di masingmasing bagian digunakan metode dokumen, serta metode observasi digunakan sebagai metode pelengkap".

Alat pengumpul data harus memenuhi persyaratan yaitu syarat validitas dan reliabilitas dalam mengungkap apa yang hendak diukur. Ada dua persyaratan yang hendak digunakan dalam pengumpulan data penelitian yaitu validitas dan reliabilitas (Hamzah, 2007:63). Validitas instrumen dalam penelitian ini meliputi dua segi yaitu validitas isi dan validitas butir. Validitas isi dibantu oleh dua orang ahli/ expert, kemudian dianalisis dengan teknik Gregory.

Sebelum instrumen digunakan, maka perlu diuji dahulu validitas dari masing-masing pertanyaan yang ada sebagai alat pengambilan data. Dengan demikian terlebih dahulu diadakan uji coba terhadap kuisioner kemudian hasil uji coba ini dianalisis. Untuk menguji 
validitas butir rumus yang digunakan adalah rumus kontribusi product moment dari Pearson (Arikunto, 1995).

Pengujian terhadap reabilitas instrumen dilakukan melalui pendekatan ketetapan internal. Uji reliabilitas adalah ketepatan dan keajegan alat pengukur tersebut dalam menilai apa yang diinginkan, artinya kapanpun alat tersebut digunakan akan diperoleh hasil yang sama (Puger, 2004). Pengujian reliabilitas dengan rumus Alpha dari Crombach (Arikunto, 1997:164).

Kegiatan analisis data terdiri atas kegiatan pengolahan data dan analisis statistik. Kegiatan analisis data meliputi: 1) menyunting data secara manual. Penyuntingan dilakukan karena kemungkinan ada data yang tidak jelas, atau kesalahan dalam pengisian instrument, sehingga tidak memenuhi syarat untuk dianalisis, 2) mentabulasi data, dan 3) mengolah data dalam bentuk sesuai kebutuhan.

Untuk menguji hipotesis yang telah dirumuskan, terlebih dahulu dilakukan analisis data yang telah dikumpulkan. Dalam melakukan analisis data untuk penelitian ini dilakukan dengan tiga tahapan yakni: 1) tahap deskripsi data, 2) tahap pengujian persyarat analisis, 3) tahap pengujian hipotesis.

Data yang telah diperoleh dari penelitian dideskripsikan menurut masing-masing variable. Oleh tujuannya seperti itu, maka akan dicari harga rerata (M), standar deviasi (SD), modus (Mo), dan median (Me) setiap variabel yang diteliti.

Setelah data dideskripsikan, maka analisis dilanjutkan dengan menggunakan teknik regresi sederhana, regresi ganda, dan korelasi varsial. Persyaratan yang berkaitan dengan teknik analisis data tersebut harus dibuktikan secara statistik.

Setelah seluruh uji prasyarat terpenuhi, maka dilanjutkan dengan uji hipotesis. Untuk menguji hipotesis pertama, kedua, ketiga dan keempat dalam penelitian ini digunakan teknik analisis korelasi sederhana (korelasi product moment pearson). Sedangkan untuk menguji hipotesis ke empat, digunakan teknik analisis korelasi ganda, regresi ganda, dan korelasi parsial. Untuk menganalisis uji hipotesis dalam penelitian ini digunakan program SPSS-17.00 for windows.

\section{HASIL PENELITIAN DAN PEMBAHASAN}

\section{Kontribusi Kepemimpianan terhadap Kinerja Pegawai}

Berdasarkan analisis data yang telah dilakukan, Secara normatif ditemukan bahwa kepemimpinan berada pada kategori baik. Selain itu, hasil analisis juga menunjukkan bahwa terdapat korelasi yang signifikan antara kepemimpinan dengan kinerja pegawai di lingkungan Rektorat Undiksha melalui persamaan garis regresi $\hat{y}=36,361+0,653$.X1dengan Freg $=$ $31,517(p<0,05)$. Sedangkan korelasi yang signifikan terjadi antara kepemimpinan dengan kinerja pegawai sebesar 0,464 dengan $p<0,05$ dan variabel kepemimpinan dapat menjelaskan kinerja pegawai di lingkungan Rektorat Undiksha sebesar 21,5\%. Temuan ini mengindikasikan bahwa kepemimpinan mempunyai peranan penting dalam meningkatkan kinerja pegawai di lingkungan Rektorat Undiksha. Sumbangan efektif (SE) variabel kepemimpinan terhadap kinerja pegawai di lingkungan Rektorat Undiksha adalah sebesar 7,61\%.

Temuan dalam penelitian ini sejalan dengan temuan penelitian yang dilakukan oleh Subawa, (2015) dengan judul "Kontribusi Gaya Kepemimpinan Pemimpin, Supervisi Akademik, dan Motivasi Berprestasi, Terhadap Kinerja Guru PNS Pada SMP Negeri Di Kabupaten Badung". Hasil penelitian menunjukkan bahwa: (1) terdapat kontribusi yang signifikan antara gaya kepemimpinan Pemimpin terhadap kinerja guru dengan koefisien korelasi sebesar 0,130 dan sumbangan efektifnya sebesar $6,32 \%$, (2) terdapat kontribusi yang signifikan antara motivasi berprestasi terhadap kinerja guru dengan koefisien korelasi sebesar 0,048 dan sumbangan efektifnya sebesar $4,60 \%$.

Hubungan kepemimpinan dapat dikaji bahwa atasan merupakan sumber motivator, agen perubahan yang tentunya perilakunya di dalam melaksanakan tugasnya sebagai pemimpin akan sangat mempengaruhi perilaku bawahannya, maka sekaligus akan mempengaruhi kinerjanya. 
Pegawai yang merasa segan dengan pimpinan tentu akan merasa malu jika menunjukan kinerja yang di bawah standar. Oleh karena itu, pimpinan yang memiliki perilaku yang baik akan menginspirasi pegawai untuk bekerja. Sehingga bisa diprediksi bahwa kepemimpinan akan berkontribusi terhadap kinerja pegawai di lingkungan Rektorat Undiksha. Berdasarkan pemaparan di atas, maka dapat disimpulkan bahwa kepemimpinan memberikan kontribusi yang signifikan terhadap kinerja pegawai di lingkungan Rektorat Undiksha.

\section{Kontribusi Kecerdasan Spiritual Terhadap Kinerja Pegawai}

Berdasarkan analisis data yang telah dilakukan, secara normatif ditemukan bahwa kecerdasan spiritual berada pada kategori sangat baik. Selain itu, hasil analisis juga menunjukkan bahwa terdapat korelasi yang signifikan antara kecerdasan spiritual dengan Di lingkungan Rektorat Undiksha melalui persamaan garis regresi $\hat{y}=34,494+0,591$ X2 dengan Freg $=39,048(p<0,05)$. Sedangkan korelasi yang signifikan terjadi antara kecerdasan spiritual dengan kinerja pegawai sebesar 0,503 dengan $p<0,05$ dan variabel kecerdasan spiritual dapat menjelaskan Di lingkungan Rektorat Undiksha sebesar 25,3\%. Temuan ini mengindikasikan bahwa kecerdasan spiritual mempunyai peranan penting dalam meningkatkan kinerja pegawai di lingkungan Rektorat Undiksha. Sumbangan efektif (SE) variabel kecerdasan spiritual terhadap kinerja pegawai di lingkungan Rektorat Undiksha adalah sebesar 9,04\%.

Temuan dalam penelitian ini sejalan dengan temuan penelitian yang dilakukan oleh Aksara (2013) yang berjudul Hubungan Antara Tingkat Kecerdasan Spiritual, Etos Kerja dan Etika Moral Terhadap Kinerja Guru Pendidikan Agama Hindu SMK di Kota Denpasar. Dalam penelitiannya dinyatakan bahwa (1) Terdapat hubungan yang positif dan signifikan antara tingkat kecerdasan spiritual terhadap kinerja guru Agama Hindu.

Kecerdasan spiritual adalah kecerdasan untuk menghadapi persoalan makna atau value, yaitu kecerdasan untuk menempatkan perilaku dan hidup kita dalam konteks makna yang lebih luas dan kaya, kecerdasan untuk menilai bahwa tindakan atau jalan hidup seseorang lebih bermakna dibandingkan yang lain. Dapat dikatakan didalam kecerdasan spiritual inilah terdapat fitrah manusia sebenarnya.

Indikasi dari kecerdasan spiritual yang berkembang mencakup: a) Kemampuan untuk bersikap fleksibel, b) Adanya tingkat kesadaran diri yang tinggi, c) Kemampuan untuk menghadapi dan memanfaatkan penderitaan, d) Kemampuan untuk menghadapi dan melampaui perasaan sakit, e) Kualitas hidup yang diilhami oleh visi dan nilai-nilai, f) Keengganan menyebabkan kerugian yang tidak perlu, g) Kecenderungan untuk berpandangan holistik, h) Kecenderungan untuk bertanya "mengapa" atau "bagaimana jika" dan berupaya untuk mencari jawaban-jawaban yang mendasar, dan kemandirian dalam berpikir.

Pegawai yang memiliki kecerdasan spiritual yang baik tentunya akan memiliki kinerja yang bagus. Sehingga diprediksi bahwa kecerdasan spiritual pegawai akan berkontribusi terhadap kinerja pegawai di lingkungan Rektorat Undiksha. Berdasarkan pemaparan di atas, maka dapat disimpulkan bahwa kecerdasan spiritual memberikan kontribusi yang signifikan terhadap kinerja pegawai di lingkungan Rektorat Undiksha.

\section{Kontribusi Motivasi Kerja Terhadap Kinerja Pegawai}

Berdasarkan analisis data yang telah dilakukan, secara normatif ditemukan bahwa motivasi kerja berada pada kategori sangat baik. Selain itu, hasil analisis juga menunjukkan bahwa terdapat korelasi yang signifikan antara motivasi kerja dengan kinerja pegawai di lingkungan Rektorat Undiksha melalui persamaan garis regresi $\hat{y}=29,833+0,709 X 3$ dengan Freg $=61,888(\mathrm{p}<0,05)$. Sedangkan korelasi yang signifikan terjadi antara motivasi kerja dengan kinerja pegawai sebesar 0,592 dengan $p<0,05$ dan variabel motivasi kerja dapat menjelaskan kinerja pegawai di lingkungan Rektorat Undiksha sebesar 35\%. Temuan ini mengindikasikan bahwa motivasi kerja mempunyai peranan penting dalam meningkatkan kinerja pegawai di lingkungan Rektorat Undiksha. Sumbangan efektif (SE) variabel motivasi kerja terhadap kinerja pegawai di lingkungan Rektorat Undiksha adalah sebesar 14,65\%. 
Hasil penelitian ini sejalan dengan hasil penelitian yang dilakukan oleh Putu Suardana (2015) dengan judul Kontribusi Persepsi Guru Tentang Gaya Kepemimpinan Pemimpin, Motivasi Kerja dan Etos Kerja terhadap Kinerja Pegawai Bahasa Inggris SMA di Kabupaten Tabanan. Hasil analisis ditemukan: (1) terdapat kontribusi yang positif dan signifikan gaya kepemimpinan Pemimpin terhadap kinerja pegawai melalui persamaan garis regresi $=3,632+$ 0,961X1 dengan Freg = 23,644 $(p<0,05)$ dan sumbangan efektif sebesar 10,30\%, (2) terdapat kontribusi yang positif dan signifikan motivasi kerja terhadap kinerja pegawai melalui persamaan garis regresi: $=42,481+0,577$ X2 dengan Freg $=21,662(p<0,05)$ dan sumbangan efektif sebesar $11,90 \%$.

Motivasi kerja merupakan kemauan atau kekuatan yang mendorong seseorang untuk melakukan kegiatan atau tugas yang harus dilaksanakan. Kemauan itu dikaitkan dalam upaya seseorang bagaimana meningkatkan kerja. Seseorang yang termotivasi adalah orang yang berupaya meningkatkan kerjanya dalam upaya mencapai tujuan. Motivasi juga dikaitkan dengan kebutuhan, kemampuan dan persepsi seseorang tentang pekerjaan. Semakin kuat motivasi yang ada pada diri pegawai dalam melaksanakan tugasnya maka prestasi kerja mereka akan semakin baik. Motivasi kerja pegawai akan mempengaruhi perilaku dalam melakukan tugas pekerjaanya.

Pegawai yang mempunyai motivasi kerja yang tinggi dan tidak hanya untuk kepentingan dirinya, akan dapat melakukan tugas dengan tepat, sesuai dengan profesinya sebagai pegawai. Sehingga motivasi kerja berkontribusi secara signifikan terhadap kinerja pegawai di lingkungan Rektorat Undiksha. Berdasarkan pemaparan di atas, maka dapat disimpulkan bahwa motivasi kerja memberikan kontribusi yang signifikan terhadap kinerja pegawai di lingkungan Rektorat Undiksha.

\section{Kontribusi Kepuasan Kerja Terhadap Kinerja Pegawai}

Berdasarkan analisis data yang telah dilakukan, secara normatif ditemukan bahwa kepuasan kerja berada pada kategori sangat baik. Selain itu, hasil analisis juga menunjukkan bahwa terdapat korelasi yang signifikan antara kepuasan kerja dengan kinerja pegawai di lingkungan Rektorat Undiksha melalui persamaan garis regresi $\hat{y}=16,553+0,825 X 4$ dengan Freg $=56,441 \quad(p<0,05)$. Sedangkan korelasi yang signifikan terjadi antara kepuasan kerja dengan kinerja pegawai sebesar 0,574 dengan $p<0,05$ dan variabel kepuasan kerja dapat menjelaskan kinerja pegawai di lingkungan Rektorat Undiksha sebesar 32,9\%. Temuan ini mengindikasikan bahwa kepuasan kerja mempunyai peranan penting dalam meningkatkan kinerja pegawai di lingkungan Rektorat Undiksha. Sumbangan efektif (SE) variabel kepuasan kerja terhadap kinerja pegawai di lingkungan Rektorat Undiksha adalah sebesar 17,83\%.

Hasil penelitian ini sejalan dengan hasil penelitian yang dilakukan oleh Wirata (2015) yang berjudul Kontribusi Supervisi Bimbingan Konseling, Iklim Kerja Sekolah dan Kepuasan Kerja Guru Terhadap Kinerja Guru Pembimbing SMA se Kabupaten Tabanan. Dalam penelitiannya dinyatakan bahwa terdapat kontribusi yang signifikan antara kepuasan kerja guru terhadap kinerja guru pembimbing dengan kontribusi sebesar 30,3\%.

Salah satu sarana penting pada manjemen sumber daya manusia dalam sebuah orgaisasi adalah terciptanya kepuasan kerja para pegawai/ karyawan. Berikut pengertianpengertian kepuasan kerja menutur beberapa pakar. Menurut Martoyo (1992: 115), kepuasan kerja pada dasarnya merupakan salah satu aspek psikologis yang mencerminkan perasaan seseorang terhadap pekerjaannya,ia akan merasa puas dengan adanya kesesuaian antara kemampuan, keterampilan dan harapannya dengan pekerjaan yang ia hadapi.

Kepuasan sebenarnya merupakan keadaan yang sifatnya subyektif yang merupakan hasil kesimpulan yang didasarkan pada suatu perbandingan mengenai apa yang diterima pegawai dari pekerjaannya dibandingkan dengan yang diharapkan, diinginkan, dan dipikirkannya sebagai hal yang pantas atau berhak atasnya. Sementara setiap karyawan/ pegawai secara subyektif menentukan bagaimana pekerjaan itu memuaskan. 
Pegawai yang mempunyai kepuasan kerja yang tinggi akan dapat melakukan tugas dengan baik dan penuh semangat. Sehingga kepuasan kerja berkontribusi secara signifikan terhadap kinerja pegawai di lingkungan Rektorat Undiksha.

\section{Kontribusi Bersama-Sama Kepemimpinan, Kecerdasan spiritual dan Motivasi Kerja Terhadap Kinerja Pegawai}

Berdasarkan analisis yang telah dilakukan, ditemukan bahwa terdapat korelasi yang signifikan secara bersama-sama antara kepemimpinan kepala sekolah, kecerdasan spiritual, motivasi kerja, dan kepuasan kerja terhadap kinerja pegawai melalui persamaan garis regresi $\hat{y}$ $=54,800+0,231 X 1+0,211 X 2+0,297 X 3+0,447 X 4$ dengan Freg $=27,008(p<0,05)$. Ini berarti terdapat hubungan secara bersama-sama antara kepemimpinan, kecerdasan spiritual, motivasi kerja, dan kepuasan kerja terhadap kinerja pegawai di lingkungan Rektorat Undiksha. Hal ini mengindikasikan bahwa makin baik kepemimpinan, kecerdasan spiritual, motivasi kerja, dan kepuasan kerja makin baik pula kinerja pegawai tersebut.

Korelasi murni antara kepemimpinan, kecerdasan spiritual, motivasi kerja, dan kepuasan kerja dengan kinerja pegawai di lingkungan Rektorat Undiksha yang diperoleh melalui analisis korelasi parsial jenjang kedua. Hasil yang diperoleh adalah: pertama, terdapat korelasi yang signifikan antara variabel kepemimpinan terhadap kinerja pegawai dengan dikendalikan oleh variabel kecerdasan spiritual, motivasi kerja, dan kepuasan kerja $\left(r_{1 y-234}=0,464\right)$ dengan $p<$ 0,05). Ini menunjukkan bahwa kepemimpinan memberikan kontribusi yang signifikan terhadap kinerja pegawai di lingkungan Rektorat Undiksha, sehingga dapat dijadikan prediktor kecenderungan tingkat kinerja pegawai di lingkungan Rektorat Undiksha.

Kedua, terdapat korelasi yang signifikan kecerdasan spiritual terhadap kinerja pegawai dengan dikendalikan oleh variabel kepemimpinan, motivasi kerja, dan kepuasan kerja $\left(\mathrm{r}_{2 \mathrm{y}-134}=\right.$ 0,503 dengan $p>0,05$ ). Ini menunjukkan bahwa kecerdasan spiritual memberikan kontribusi terhadap kinerja pegawai di lingkungan Rektorat Undiksha, sehingga dapat dijadikan prediktor kecenderungan tingkat kinerja pegawai di lingkungan Rektorat Undiksha.

Ketiga, terdapat korelasi yang signifikan antara motivasi kerja terhadap kinerja pegawai dengan dikendalikan oleh variabel kepemimpinan, kecerdasan spiritual, dan kepuasan kerja $\left(r_{3 y-124}=0,592\right.$ dengan $\left.p>0,05\right)$. Ini menunjukkan bahwa motivasi kerja memberikan kontribusi terhadap kinerja pegawai di lingkungan Rektorat Undiksha, sehingga dapat dijadikan prediktor kecenderungan tingkat kinerja pegawai di lingkungan Rektorat Undiksha.

Keempat, terdapat korelasi yang signifikan antara kepuasan kerja terhadap kinerja pegawai dengan dikendalikan oleh variabel kepemimpinan, kecerdasan spiritual dan motivasi kerja $\left(r_{4 y-123}=0,574\right.$ dengan $\left.p>0,05\right)$. Ini menunjukkan bahwa kepuasan kerja memberikan kontribusi terhadap kinerja pegawai di lingkungan Rektorat Undiksha, sehingga dapat dijadikan prediktor kecenderungan tingkat kinerja pegawai di lingkungan Rektorat Undiksha.

Kekuatan hubungan keempat variabel bebas dengan kinerja pegawai di lingkungan Rektorat Undiksha secara berurutan adalah: kepemimpinan, kecerdasan spiritual, motivasi kerja, dan kepuasan kerja mempunyai kontribusi terhadap kinerja pegawai.

\section{PENUTUP}

Berdasarkan hasil penelitian dan pembahasan yang telah dilakukan, maka dapat ditarik kesimpulan sebagai berikut.

Pertama, ada kontribusi yang signifikan antara kepemimpinan terhadap kinerja pegawai di lingkungan Rektorat Undiksha dengan koefisien korelasi sebesar 0,464 dan sumbangan efektifnya sebesar $7,61 \%$.

Kedua, ada kontribusi yang signifikan antara kecerdasan spiritual terhadap kinerja pegawai di lingkungan Rektorat Undiksha. dengan koefisien korelasi sebesar 0,503 dan sumbangan efektifnya sebesar $9,04 \%$. 
Ketiga, ada kontribusi yang signifikan antara motivasi kerja terhadap kinerja pegawai di lingkungan Rektorat Undiksha dengan koefisien korelasi sebesar 0,592 dan sumbangan efektifnya sebesar $14,65 \%$.

Keempat, ada kontribusi yang signifikan antara kepuasan kerja terhadap kinerja pegawai di lingkungan Rektorat Undiksha dengan koefisien korelasi sebesar 0,574 dan sumbangan efektifnya sebesar $17,83 \%$.

Kelima, secara bersama-sama, ada kontribusi yang signifikan antara kepemimpinan, kecerdasan spiritual, motivasi kerja, dan kepuasan kerja terhadap kinerja pegawai di lingkungan Rektorat Undiksha dengan koefisien korelasi ganda sebesar 0,701 dan kontribusinya sebesar 49,1\% terhadap kinerja pegawai di lingkungan Rektorat Undiksha.

Berdasarkan hasil dan kesimpulan dari penelitian ini, dapat diajukan beberapa saran sebagai berikut.

Pegawai hendaknya mampu untuk meningkatkan motivasi kerja yang dimiliki sehingga kualitas kinerja pegawai dapat ditingkatkan. Hal ini bertujuan agar kinerja yang ada di dalam sebuah lembaga dapat berjalan secara optimal, sehingga tujuan sebuah lembaga yang ingin dicapai dapat tercapai secara maksimal.

Pimpinan hendaknya mampu untuk meningkatkan kepemimpinannya, sehingga pimpinan akan menjadi panutan bagi pegawai yang ada di lingkungan Rektorat Undiksha. Selain itu pimpinan hendaknya juga mampu untuk mengayomi seluruh bawahannya sehingga kegiatankegiatan di lembaga dapat berjalan dengan optimal.

Peneliti lain diharapkan mampu mengembangkan variabel lain dalam usaha meningkatkan kinerja pegawai, sehingga dapat memberikan kontribusi pengetahuan.

\section{DAFTAR RUJUKAN}

Agung, Anak Agung Gede. 2014. Metodologi Penelitian Pendidikan. Malang: Aditya Media Publishing.

Agung, Anak Agung Gede. 2016. Statistika Dasar untuk Pendidikan. Yogyakarta; Depublish.

Aksara, I Pt Batu. 2013. Hubungan Antara Tingkat Kecerdasan Spiritual, Etos Kerja dan Etika Moral Terhadap Kinerja Guru Pendidikan Agama Hindu SMK di Kota Denpasar. E-Jurnal Pascasarjana Undiksha Volume 4 Nomor 1.

Arikunto, Suharsimi. 1995. Manajemen Penelitian. Jakarta: Rineka Cipta.

Arikunto, Suharsimi. 1997. Prosedur Penelitian Suatu Pendekatan Praktek. Jakarta: Rineka Cipta.

Hamzah, B. Uno. 2007. Teori Motivasi dan Pengukurannya. Jakarta: Bumi Aksana.

Handoko T. Hani. 2000. Manajemen Personalia dan Sumberdaya Manusia, Edisi II, Cetakan Keempat Belas. Yogyakarta: BPFE.

Handoko, T. Hani. 1995. Manajemen. Yogyakarta: BPFE

Hariandja, Marihot T.E, 2002. Manajemen Sumber Daya Manusia. Jakarta: Grasindo

Suardana, Putu. 2015. Kontribusi Persepsi Guru Tentang Gaya Kepemimpinan Pemimpin, Motivasi Kerja dan Etos Kerja terhadap Kinerja Pegawai Bahasa Inggris SMA di Kabupaten Tabanan. e-Jurnal Administrasi Pendidikan. Vol 6, No 1.

Robbins, Stephen P. and Coulter, Mary. 2012. Management. New Jersey: Pearson.

Robbins SP, dan Judge. 2008. Perilaku Organisasi Buku 2,.Jakarta : Salemba Empat 
Sinambela, Lijan. 2012. Kinerja Pegawai: Teori, Pengukuran dan Implikasi. Yogyakarta: Graha IImu.

Subawa, I Made. 2015. Kontribusi Gaya Kepemimpinan Kepala Sekolah, Supervisi Akademik, dan Motivasi Berprestasi, Terhadap Kinerja Guru PNS pada SMP Negeri Di Kecamatan Gerokgak. e-Jurnal Administrasi Pendidikan. Vol 6, No 1.

Sugiyono. 2009. Statistika Untuk Penelitian. Bandung: Alfabeta

Wirata, I Made Suka. 2015. Kontribusi Supervisi Bimbingan Konseling, Iklim Kerja Sekolah dan Kepuasan Kerja Guru Terhadap Kinerja Guru Pembimbing SMA se Kabupaten Tabanan. e-Jurnal Pascasarjana Undiksha Volume 6 Nomor 1. 